Monographs in Oral Science 


\section{Monographs in Oral Science}

\section{Vol. 17}

Series Editor

G.M. Whitford, Augusta, Ga.

KARGER $\quad \begin{aligned} & \text { Basel·Freiburg. Paris·London } \cdot \text { New York } \\ & \text { New Delhi·Bangkok·Singapore·Tokyo·Sydney }\end{aligned}$ 


\title{
Assessment of Oral Health
}

\section{Diagnostic Techniques and Validation Criteria}

\author{
Volume Editor R.V. Faller, Mason, Ohio
}

81 figures, 17 in color, and 20 tables, 2000

\footnotetext{
KAGER Basel-Freiburg. Paris.London - New York.

New Delhi · Bangkok · Singapore · Tokyo · Sydney
} 


\section{(n)}

\section{R.V. Faller}

The Procter \& Gamble Company

Health Care Research Center

8700 Mason-Montgomery Road

Mason, OH 45040-9462

Library of Congress Cataloging-in-Publication Data

Assessment of oral health : diagnostic techniques and validation criteria / volume editor, R.V. Faller.

p. ; cm. - (Monographs in oral science, ISSN 0077-0892; vol. 17)

Includes bibliographical references and indexes.

ISBN 3805570309 (alk. paper)

1. Mouth - Diseases - Diagnosis. 2. Teeth - Diseases - Diagnosis. 3. Oral manifestations

of general diseases. I. Faller, R.V. II. Series.

[DNLM: 1. Diagnosis, Oral - methods. 2. Mouth Diseases - diagnosis. 3. Tooth

Diseases - diagnosis. WU 141 A846 2000]

RC815.A856 2000

616. 3'1075-dc21

$00-038432$

Drug Dosage. The authors and the publisher have exerted every effort to ensure that drug selection and dosage set forth in this text are in accord with current recommendations and practice at the time of publication. However, in view of ongoing research, changes in government regulations, and the constant flow of information relating to drug therapy and drug reactions, the reader is urged to check the package insert for each drug for any change in indications and dosage and for added warnings and precautions. This is particularly important when the recommended agent is a new and/or infrequently employed drug.

All rights reserved. No part of this publication may be translated into other languages, reproduced or utilized in any form or by any means electronic or mechanical, including photocopying, recording, microcopying, or by any information storage and retrieval system, without permission in writing from the publisher.

(C) Copyright 2000 by S. Karger AG, P.O. Box, $\mathrm{CH}-4009$ Basel (Switzerland)

www.karger.com

Printed in Switzerland on acid-free paper by Reinhardt Druck, Basel

ISSN 0077-0892

ISBN 3-8055-7030-9 


\section{Contents}

VII Preface

1 Direct Digital Radiography for Caries Detection and Analysis Analoui, M.; Stookey, G.K. (Indianapolis, Ind.)

20 Relationship of Surface Epithelium Concentrations of IL-1 $\alpha$ and IL-1及 to Cinical Inflammation during Experimental Gingivitis Biesbrock, A.; Yeh, C.H. (Cincinnati, Ohio)

32 Imaging of the Oral Cavity Using Optical Coherence Tomography Colston, B.W., Jr.; Everett, M.J.; Sathyam, U.S.; DaSilva, L.B. (Livermore, Calif.); Otis, L.L. (Stanford, Conn.)

56 Advances in Measurements of Periodontal Bone and Attachment Loss Jeffcoat, M.K., Reddy, M.S. (Birmingham, Ala.)

73 Analysis of the Morphology of Oral Structures from 3-D Co-Ordinate Data Jovanovski, V.; Lynch, E. (London)

130 Objective Quantification of Plaque Using Digital Image Analysis Sagel, P.A.; Lapujade, P.G.; Miller, J.M.; Sunberg, R.J. (Mason, Ohio)

144 Application of Quantitative Light-Induced Fluorescence for Assessing Early Caries Lesions

van der Veen, M.H.; de Josselin de Jong, E. (Amsterdam) 
163 Recent Advances in Methods for the Assessment of Dental Calculus Research and Clinical Implications

White, D.J. (Cincinnati, Ohio)

174 Characterization and Validation of Diagnostic Methods ten Bosch J.J. (Groningen); Angmar-Månsson, B. (Huddinge)

190 Author Index

191 Subject Index 


\section{. \\ Preface}

Over the past several years, a number of new methods have been developed for use in the diagnosis of oral disease states. Some of these methods may be applicable to dental practitioners and others may have greater applicability in a clinical situation. This volume of Monographs in Oral Science provides a description of a wide range of new oral diagnostic methods. A number of these methods are focused toward the specific assessment of disease states such as caries, calculus, plaque, gingivitis and periodontal disease. Other methods are more broad, focusing on methods to measure specific changes in oral morphology. Regardless of the method described, similarities exist when it comes to the validation of each method for general acceptance and use. Each method must be critically assessed in order to determine whether or not an appropriate validation has been done to confirm the robust nature of the technique or application.

The first eight chapters of this monograph provide descriptions of a range of new oral diagnostic techniques, the final chapter discusses considerations that must be taken into account regarding the validation requirements for each. While this monograph provides an overview of a series of specific new oral diagnostic methods, these are certainly not the only new methods under development for assessing oral disease states or morphology. Regardless of the technique being developed, the validation criteria laid out are applicable to any new oral diagnostic method.

R. V. Faller 